\title{
Znaczenie prognostyczne minimalnej choroby resztkowej ocenianej metodą cytometrii przepływowej w ostrej białaczce szpikowej
}

\author{
Prognostic significance of minimal residual disease \\ assessed by flow cytometry in acute myeloid leukemia
}

\author{
Edyta Ponikowska-Szyba ${ }^{1}$, Jolanta Woźniak² ${ }^{2}$ Joanna Góra-Tybor ${ }^{3}$ \\ ${ }^{1}$ Klinika Hematologii i Transplantacji Szpiku, Świętokrzyskie Centrum Onkologii, Kielce \\ ${ }^{2}$ Zakład Diagnostyki Hematologicznej, Instytut Hematologii i Transfuzjologii, Warszawa \\ ${ }^{3}$ Klinika Hematologii, Instytut Hematologii i Transfuzjologii, Warszawa
}

\begin{abstract}
Streszczenie
Mimo wysokiego odsetka catkowitych remisji po chemioterapii indukujacej odlegte wyniki leczenia chorych na ostre białaczki szpikowe (AML) pozostaja niezadowalajace. Pozostate po leczeniu komórki biataczkowe niewykrywalne standardowymi metodami oceny remisji, czyli tak zwana minimalna choroba resztkowa (MRD), stanowia punkt wyjścia dla częstych nawrotów choroby. Dlatego monitorowanie MRD metodami o wysokiej czutości, na przyktad cytometrii przeplywowej, budzi ostatnio duże zainteresowanie. W większości badań potwierdza się znaczenie prognostyczne MRD jako niezależnego czynnika ryzyka wznowy $i$ zgonu w AML. Co wiecej, parametr ten w potaczeniu ze zmianami cytogenetyczno-molekularnymi pozwala na doktadniejsza ocene ryzyka i zastosowanie adekwatnej do niego terapii. Brak standaryzacji metody utrudnia jednak wprowadzenie jej do rutynowej praktyki klinicznej.
\end{abstract}

Słowa kluczowe: ostra białaczka szpikowa, minimalna choroba resztkowa, wielokolorowa cytometria przepływowa

Hematologia 2016; 7, 2: 97-107

\begin{abstract}
Despite high complete remission rate after induction chemotherapy, long-term prognosis for acute myeloid leukemia (AML) patients is still unsatisfactory. Leukemic blast cells remaining after therapy, which cannot be detected by standard method for response assessment in AML, termed minimal residual disease (MRD) are responsible for frequent relapses. High sensitivity methods, e.g. flow cytometry are being widely studied for MRD monitoring. Majority of studies confirm this parameter to be an independent risk factor for relapse and death in AML. What is more, MRD assessment is thought to be complementary to cytogenetic and molecular aberrancies in risk stratification and applying more adequate risk-adapted therapy. However, lack of method standardization is an obstacle to its incorporation into clinical practice.
\end{abstract}

Key words: acute myeloid leukemia, minimal residual disease, multiparameter flow cytometry

Hematologia 2016; 7, 2: 97-107

Adres do korespondencji: Edyta Ponikowska-Szyba, Klinika Hematologii i Transplantacji Szpiku, Świętokrzyskie Centrum Onkologii, ul. Artwińskiego 3, 25-734 Kielce, tel. 4136748 41, faks 41367 48 39, e-mail: edyta.szyba@gmail.com 


\section{Wprowadzenie}

Ostre białaczki szpikowe (AML, acute myeloid leukemia) stanowią około $80 \%$ wszystkich ostrych białaczek u dorosłych. Zapadalność na AML wynosi średnio 4,0/100 tys./rok i zwiększa się $z$ wiekiem, a mediana wieku w momencie rozpoznania to 67 lat. Po zastosowaniu standardowego leczenia indukującego u 50-80\% chorych udaje się uzyskać całkowitą remisję (CR), jednak u większości z nich dochodzi do wznowy choroby. Według badań Polskiej Grupy ds. Leczenia Białaczek u Dorosłych (PALG, Polish Adult Leukemia Group) odsetek 3-letniego całkowitego przeżycia (OS, overall survival) wśród chorych, u których można zastosować intensywną chemioterapię, wynosi 38\% [1]. Z kolei według amerykańskich danych epidemiologicznych (SEER 2005-2011) 5-letnie OS osiąga niespełna 26\% chorych na AML [2].

Jedną z głównych przyczyn tak niekorzystnego rokowania w AML są nawroty choroby, za które są odpowiedzialne pozostałe po leczeniu komórki białaczkowe, niewykrywalne standardowymi metodami oceny remisji, czyli tak zwana minimalna choroba resztkowa (MRD, minimal residual disease). W przypadku AML stan całkowitej remisji nadal określa się na podstawie morfologicznej oceny odsetka blastów w rozmazach szpiku (tj. $<5 \%$, przy braku obecności blastów $z$ pałkami Auera), w połączeniu $z$ regeneracją prawidłowej hematopoezy (liczba neutrofilów > 1,0 G/L, liczba płytek $>100 \mathrm{G} / \mathrm{L}$, niezależność od przetoczeń koncentratu krwinek czerwonych) oraz brakiem pozaszpikowych ognisk białaczki. Niska czułość oceny morfologicznej (1-5\%) nie pozwala wyodrębnić pacjentów nadal zagrożonych dużym ryzykiem niepowodzenia leczenia, tj. wznowy i zgonu [3]. Co więcej, zaobserwowano istotne rozbieżności między oceną morfologiczną blastów a oceną za pomocą wielokolorowej cytometrii przepływowej (MFC, multiparameter flow cytometry). Inaba i wsp. porównali skuteczność metod oceny remisji w grupie 205 dzieci z AML [4]. W 8\% próbek ocenianych jako morfologiczna CR stwierdzono obecność więcej niż 5\% blastów białaczkowych w ocenie MFC. $Z$ kolei w $57 \%$ próbek ocenionych morfologicznie jako brak CR stwierdzono obecność mniej niż 5\% blastów białaczkowych w ocenie fenotypowej. Wyniki uzyskane za pomocą MFC silniej korelowały z przebiegiem klinicznym [4].

$\mathrm{W}$ onkohematologii, podobnie jak w innych dziedzinach medycyny, rodzaj terapii powinien być dostosowany do ryzyka, na które składają się zarówno czynniki zależne od pacjenta, jak i od samej choroby. Rozbudowane skale prognostyczne mają umożliwić wybór najbardziej adekwatnej w danej sytuacji klinicznej metody leczenia. Wśród czynników rokowniczych można wyróżnić dwie zasadnicze grupy - czynniki statyczne, określane na podstawie danych uzyskanych w chwili rozpoznania, oraz dynamiczne, określane w trakcie terapii i po jej zakończeniu, odzwierciedlające aktualną odpowiedź na zastosowane leczenie. Obecnie najważniejszymi niezależnymi czynnikami ryzyka w AML są zmiany cytogenetyczno-molekularne klonu białaczkowego określane w chwili diagnozy $[5,6]$. Ich obecność pozwala zakwalifikować chorego do jednej z trzech grup ryzyka - korzystnego, pośredniego lub niekorzystnego. Jednak, mimo intensywnego rozwoju metod diagnostycznych i wykrywania coraz większej liczby aberracji genetycznych o znaczeniu rokowniczym, nadal ponad $60 \%$ pacjentów znajduje się w bardzo heterogennej grupie ryzyka pośredniego [7]. Co więcej, u 30-40\% pacjentów z grupy ryzyka korzystnego również obserwuje się wznowę choroby [8]. Dlatego celowe wydaje się poszukiwanie innych, dynamicznych czynników prognostycznych, które umożliwiłyby modyfikację leczenia poremisyjnego zależnie od odpowiedzi na leczenie indukujące i konsolidujące.

Ze względu na fakt, że morfologiczne kryteria CR nie są wystarczająco czułe, istotnych danych może dostarczyć ocena MRD metodami o wysokiej czułości, tj. za pomocą łańcuchowej reakcji polimerazy (PCR, polymerase chain reaction) lub MFC. Ocena znaczenia rokowniczego MRD w AML była w ostatnich latach przedmiotem wielu badań, trzeba jednak podkreślić, ̇̇e ze względu na dużą heterogenność AML i brak standaryzacji metod diagnostycznych ocena MRD nie została dotychczas włączona do algorytmu postępowania w praktyce klinicznej, jak to ma miejsce na przykład w odniesieniu do ostrej białaczki limfoblastycznej (ALL, acute lymphoblastic leukemia), ostrej białaczki promielocytowej (APL, acute promyelocytic leukemia) lub przewlekłej białaczki szpikowej (CML, chronic myelogenous leukemia) $[9,10]$.

W pracy omówiono aktualne wyniki badań dotyczące znaczenia prognostycznego MRD ocenianej metodą MFC u chorych na AML.

\section{Ocena MRD w AML za pomocą cytometrii przepływowej}

W przebiegu prawidłowej hematopoezy zmiany ekspresji antygenów powierzchniowych komórki mieloidalnej są odzwierciedleniem wewnątrzkomórkowych procesów zachodzących w trakcie jej 
Tabela 1. Panele antygenów stosowane do identyfikacji aberrantnych fenotypów w ostrej białaczce szpikowej (źródło [9])

Table 1. Antigen panel used for identifying aberrant phenotype in acute myeloid leukemia (source [9])

\begin{tabular}{|l|l|}
\hline Rodzaj aberrantnego fenotypu & Ekspresja antygenów \\
\hline Antygeny typowe dla blastów i linii mieloidalnej & CD34, CD45, CD117, CD133, HLA-DR, CD13, CD15, CD33 \\
\hline Abberantna ekspresja antygenów limfoidalnych & $\mathrm{CD} 2, \mathrm{CD} 7, \mathrm{CD} 19, \mathrm{CD} 22, \mathrm{CD} 56$ \\
\hline Antygeny mielomonocytowe i megakariocytowe & $\mathrm{CD} 4, \mathrm{CD} 11 \mathrm{~b}, \mathrm{CD} 14, \mathrm{CD} 36, \mathrm{CD} 64$ \\
\hline Antygeny typowe dla komórek pnia i progenitorowych & $\mathrm{CD} 34 / \mathrm{CD} 117 / \mathrm{CD} 38, \mathrm{CD} 45 \mathrm{RA} / \mathrm{CD} 123$ \\
\hline
\end{tabular}

dojrzewania i w związku $z$ tym mają zawsze taką samą, określoną sekwencję. Transformacja nowotworowa powoduje zaburzenia w ekspresji tych antygenów, co można zbadać metodą cytometrii przepływowej. Aberrantny zestaw antygenów, pozwalający odróżnić komórki klonu białaczkowego od komórek prawidłowej hematopoezy, określa się mianem fenotypu związanego $z$ białaczką (LAIP, leukemia-associated immunophenotype).

Najczęściej spotykane typy aberracji antygenowych w AML to: 1) obecność antygenów charakterystycznych dla innych linii komórkowych, na przykład obecność antygenów limfoidalnych (np. CD2, CD3, CD5, CD7, CD10, CD19, CD56); 2) asynchroniczna ekspresja antygenów, tj. jednoczesna obecność na komórce białaczkowej antygenów charakterystycznych dla komórek prekursorowych (np. CD34) i dojrzałych (np. CD15); 3) nadmierna lub słabsza ekspresja antygenu; 4) odmienna charakterystyka w zakresie parametrów wielkości i ziarnistości komórek blastycznych powodująca ich zmienioną lokalizację na tak zwanych wykresach rozproszenia FSC (forward scatter) i SSC (side scatter); 5) brak ekspresji antygenów charakterystycznych dla linii mieloidalnej (np. CD13, CD33) (tab. 1). Przyjmuje się, że punktem odcięcia dla wartości pozytywnej danego antygenu jest jego ekspresja na $20 \%$ komórek białaczkowych, a dla aberrantnej koekspresji dwóch antygenów - ich wspólna obecność na minimum $50 \%$ komórek białaczkowych [3, 11-13]. U znaczącej części chorych w chwili rozpoznania można stwierdzić nawet dwa lub więcej aberrantnych fenotypów, czyli LAIP, co odzwierciedla heterogenność populacji komórek białaczkowych [11, 13]. Inną metodą służącą identyfikacji choroby resztkowej, przydatną zwłaszcza wtedy, gdy nie ma do dyspozycji LAIP (brak fenotypu aberrantnego u danego chorego lub brak dostępu do próbek szpiku $z$ momentu rozpoznania), jest strategia polegająca na porównaniu charakterystyki fenotypowej komórek szpiku pacjenta $z$ charakterystyką fenotypową prawidłowego, regenerującego szpiku i wykazaniu populacji komórek wykraczających poza ten określony schemat [14].

Do niewątpliwych zalet MFC należą szybkość wykonania analizy (kilka godzin) oraz względnie niskie koszty. Poza tym czułość tej metody niewiele ustępuje metodom molekularnym, umożliwiając wykrycie jednej komórki białaczkowej na 1000 -10000 komórek $\left(10^{-3}-10^{-4}\right)$. Kolejną zaletą MFC jest możliwość zastosowania tej metody u większości chorych na AML (60-94\%), natomiast tylko u 60-70\% pacjentów można stwierdzić zaburzenia genetyczne umożliwiające monitorowanie MRD ilościową PCR w czasie rzeczywistym [3, 11].

Należy jednak podkreślić, że ocena MRD metodą cytometrii przepływowej ma również swoje ograniczenia. Wynikają one przede wszystkim $z$ niestabilności immunofenotypowej klonu białaczkowego. Okazuje się, że aż w $91 \%$ przypadków można wykazać różnicę dotyczącą ekspresji przynajmniej jednego antygenu między LAIP określonym $\mathrm{w}$ chwili diagnozy i w momencie wznowy choroby, czyli tak zwany antigenic shift $[11,15]$. Przyczyną tego zjawiska może być niestabilność w obrębie wyjściowego klonu białaczkowego, rozrost subklonu opornego na chemioterapię, który $\mathrm{w}$ chwili diagnozy stanowił niewielką liczbę komórek białaczkowych (poniżej progu detekcji) lub nie miał wystarczająco aberrantnego fenotypu i wobec tego nie wchodził w zakres monitorowania MRD albo powstanie zupełnie nowego klonu [11]. Efektem tego zjawiska mogą być fałszywie ujemne wyniki badania. Aby im zapobiec, konieczne jest stosowanie odpowiednio szerokiego panelu przeciwciał przy rozpoznaniu, pozwalającego na wykrycie wszystkich, nawet najmniejszych, subpopulacji komórek białaczkowych, a następnie ocena MRD pod względem wszystkich określonych LAIP $[3,13,16,17]$. Jest to możliwe dzięki zastosowaniu 6-10-kolorowych cytometrów (w Polsce stosuje się najczęściej 6-8 kolorów). Mimo to nadal u około $1 / 3$ młodszych chorych (podobne wyniki w grupach pediatrycznych) $z$ ujemnym wynikiem MRD po 
leczeniu indukującym i konsolidującym obserwuje się wznowę choroby [14]. Wydaje się, że dalsze zwiększanie liczby jednocześnie oznaczanych antygenów nie będzie możliwe do zastosowania w codziennej praktyce ze względu na stopień skomplikowania procedury oraz ze względu na wzrost kosztów badania. Być może, oznaczanie MRD na podstawie identyfikacji blastów stanowiących mase nowotworu nie jest wystarczającym podejściem i alternatywą dla rozszerzania panelu przeciwciał mogłoby być uzupełnienie oceny o badanie populacji macierzystych komórek białaczkowych (LSC, leukemic stem cells). Komórki macierzyste - zarówno prawidłowe, jak i białaczkowe - zawarte są przede wszystkim w populacji CD34(+)/CD38(-), a główny problem polega na ich odróżnieniu. Na podstawie dotychczas przeprowadzonych badań stwierdzono, że takie antygeny, jak: CD2, CD7, CD11b, CD19, CD22, CD56, CLL-1 (C-type lectin-like molecule-1), mogą być obecne na LSC, natomiast nigdy nie występują na prawidłowych krwiotwórczych komórkach macierzystych (HSC, hematopoietic stem cells). Z kolei markery, tj. CD13, CD33, HLA-DR, zawsze są obecne na HSC, a ich brak może być składową aberrantnego fenotypu LSC [18, 19]. Jednak w około $25 \%$ przypadków nie udaje się jednoznacznie wyodrębnić subpopulacji LSC w populacji komórek CD34(+)/CD38(-) na podstawie aberrantnej ekspresji antygenów. Wówczas pomocne może być zróżnicowanie w zakresie FSC i SSC (wyższe wartości dla LSC) [19]. Jak wykazano w pracy Terwijn i wsp. [19], połączenie oceny MRD (punkt odcięcia dla wartości dodatniej - 0,1\%) i LSC dostarcza dodatkowych danych do oceny ryzyka u chorych na AML. Spośród czterech wyodrębnionych grup pacjentów, tj. $\mathrm{LSC}(+) / \mathrm{MRD}(+), \operatorname{LSC}(+) /$ /MRD(-), LSC(-)/MRD(+), LSC(-)/MRD(-), grupa LSC (-)/MRD(-) charakteryzowała się najlepszym, a $\operatorname{LSC}(+) / \mathrm{MRD}(+)$ najgorszym rokowaniem. Co ciekawe, wykazano, że wśród chorych MRD(-) rokowanie pacjentów $\operatorname{LSC}(-)$ jest istotnie lepsze niż pacjentów $\mathrm{LSC}(+)(\mathrm{p}=0,01), z$ kolei $\mathrm{w}$ grupie chorych LSC $(+)$ pacjentów MRD(-) cechuje lepsze rokowanie niż pacjentów $\mathrm{MRD}(+)(\mathrm{p}=0,04)$ [19]. Choć ocena LSC wydaje się racjonalnym krokiem w kierunku dokładniejszej oceny ryzyka u chorych na AML, to problemem może być czułość badania uwarunkowana małą liczebnością tej populacji.

Kolejnym utrudnieniem w cytometrycznej ocenie MRD jest fakt, że niektóre zaburzenia ekspresji antygenów mogą występować w niewielkim odsetku na komórkach regenerującego się szpiku (np. po chemioterapii, po zastosowaniu czynników wzrostu), a nawet w szpiku osób zdrowych (np. niska ekspresja antygenów limfoidalnych CD2 i/lub CD7 na komórkach mieloidalnych) [11]. Jakość wykrywania fenotypów aberrantnych zależy więc od kilku podstawowych czynników: specyfiki LAIP, tj. poziomu ich ekspresji $\mathrm{w}$ regenerującym szpiku (wysoka specyficzność, gdy LAIP wynosi $<0,1 \%$ ), czułości zależnej od wielkości ekspresji LAIP na komórkach białaczkowych w momencie diagnozy (>50\% komórek białaczkowych), liczby przeanalizowanych komórek, liczby ocenianych jednocześnie antygenów (wielokolorowa cytometria), strategii bramkowania oraz stabilności LAIP (możliwości wykrywania w trakcie leczenia i we wznowie).

Bardzo istotnym czynnikiem prawidłowej oceny MRD jest jakość próbki, a przede wszystkim brak rozcieńczenia badanego aspiratu szpiku krwią obwodową [4, 20]. Mimo coraz powszechniejszego stosowania MFC do oceny remisji u chorych na AML metoda ta wciąż nie jest wystandaryzowana. Stosuje się różne panele przeciwciał, a odsetek komórek patologicznych jest wyrażany w odniesieniu do różnych populacji komórek, tj. wszystkich komórek jądrzastych, mononuklearów, komórek CD45+. Dyskusyjny pozostaje również próg czułości, jaki powinno się przyjąć dla ujemnej wartości MRD. Dlatego kluczowe znaczenie mają wiedza i doświadczenie osoby wykonującej badanie.

\section{Znaczenie prognostyczne oceny MRD po terapii indukującej i konsolidującej}

Znaczenie prognostyczne MRD w AML budzi zainteresowanie badaczy od ponad trzech dekad. Jednak większość badań to analizy retrospektywne, jednoośrodkowe, obejmujące niewielkie grupy pacjentów. I choć potwierdzają one przydatność tego parametru w ocenie ryzyka wznowy u chorych na AML, to bezpośrednie porównanie ich wyników utrudniają różnorodność zastosowanej metodyki oraz odmienne definicje ujemnego i dodatniego wyniku MRD [11].

W jednym $z$ pierwszych badań $z$ wykorzystaniem MFC do oceny MRD San Miguel i wsp. [12] wykazali istotną statystycznie zależność między obecnością MRD a zwiększonym odsetkiem nawrotów choroby, krótszym czasem wolnym od nawrotu (RFS, relapse-free survival) oraz krótszym OS u 53 chorych na AML poddanych intensywnej chemioterapii. Badacze oceniali MRD na podstawie liczby komórek $z$ aberrantnym fenotypem w stosunku do wszystkich komórek jądrzastych szpiku i przyjęli dwa punkty odcięcia dla wartości dodat- 
niej MRD zależnie od czasu, w którym dokonano oceny - $0,5 \%$ lub więcej po indukcji i $0,2 \%$ lub więcej po konsolidacji. Częstość nawrotów choroby u pacjentów $z \mathrm{MRD}(+)$ po indukcji wynosiła $67 \%$ w stosunku do $20 \%$ w grupie MRD $(-)(\mathrm{p}=0,002)$. $\mathrm{W}$ ocenie po konsolidacji wartości te wynosiły, odpowiednio, $69 \%$ i $32 \%$ ( $\mathrm{p}=0,02)$. Podobnie mediana RFS w grupie pacjentów $z \mathrm{MRD}(+)$ po indukcji wynosiła 17 miesięcy, a w $\operatorname{MRD}(+)$ po konsolidacji - 16 miesięcy, natomiast $\mathrm{w}$ grupie $\mathrm{MRD}(-) \mathrm{w}$ obu punktach czasowych nie została osiągnięta $(\mathrm{p}=0,01 ; \mathrm{p}=0,04)$. W przypadku OS jedynie dodatni wynik MRD po konsolidacji osiągnął istotność statystyczną; mediana w grupie $\mathrm{MRD}(+)$ wynosiła 25 miesięcy, w grupie MRD(-) zaś nie została osiągnięta $(\mathrm{p}=0,008)$. Analiza wielowariantowa wykazała, że obecność MRD po indukcji i po konsolidacji jest najsilniejszym, niezależnym czynnikiem ryzyka wznowy u chorych na AML $\mathrm{w}$ pierwszej remisji [12].

$Z$ kolei w innej pracy tego samego autora analizie poddano tylko wczesną ocenę MRD, po indukcji u 126 chorych na AML. W badaniu tym wyodrębniono trzy grupy ryzyka zależnie od wielkości choroby resztkowej - grupę wysokiego ryzyka z poziomem MDR równym $1 \%$ lub wyższym, grupę ryzyka pośredniego $z$ MRD niższym niż $1 \%$ i równym lub wyższym od $0,1 \%$ oraz grupę niskiego ryzyka $z$ MRD niższym niż $0,1 \%$. Trzyletni skumulowany wskaźnik nawrotów choroby w poszczególnych grupach ryzyka wynosil, odpowiednio, $85 \%, 45 \%$ i $14 \%$ ( $p<0,0001)$. Ponadto $\mathrm{w}$ grupie niskiego ryzyka $18 \%$ pacjentów osiągnęło redukcję MRD do poziomu niższego niż $0,01 \%$ i u żadnego $z$ nich nie obserwowano wznowy choroby. Poziom MRD po indukcji korelował również z prawdopodobieństwem OS; 3-letnie OS osiągnęło 29\%, $62 \%$ i $90 \%$ chorych, odpowiednio, $z$ grupy ryzyka wysokiego, pośredniego i niskiego ( $<<0,001)$ [21].

Podobne wyniki obserwowali Inoue i wsp. [22] w grupie 33 japońskich pacjentów $z$ nowo rozpoznaną AML poddanych intensywnej chemioterapii. Badacze podzielili chorych, w zależności od statusu MRD po indukcji, na dwie grupy - A obejmującą 20 chorych $z$ obecną chorobą resztkową, $\mathrm{MRD}(+)$ i B obejmującą 13 chorych bez wykrywalnej choroby resztkowej, MRD(-). Status MRD(+) przyznawano chorym $z$ ponad $0,1 \%$ komórek $z$ aberrantnym fenotypem w stosunku do wszystkich komórek jądrzastych szpiku. Wykazano, że prawdopodobieństwo OS w grupie A było istotnie mniejsze niż $\mathrm{w}$ grupie B (2-letnie OS wyniosło, odpowiednio, $49 \%$ i $84,6 \%$; $p=0,0317$, a RFS - $13,7 \%$ i $91,7 \%$; $\mathrm{p}=0,001)$. W analizie wielowariantowej obecność choroby resztkowej po indukcji była niezależnym czynnikiem ryzyka krótszego RFS. Dodatkowo badacze ocenili rokowanie u pacjentów $\mathrm{MRD}(+)$ w zależności od dynamiki zmian MRD (spadek lub wzrost) po konsolidacji i nie wykazali między nimi istotnych różnic w odniesieniu do OS i RFS. Warto dodać, że tylko 2 pacjentów z MRD(+) uzyskało negatywizację MRD po chemioterapii konsolidującej, $z$ kolei 4 pacjentów $z \operatorname{MRD}(+)$ poddanych przeszczepieniu allogenicznych krwiotwórczych komórek macierzystych (allo-HSCT, allogeneic hematopoietic stem cell transplantation) pozostawało w CR z medianą obserwacji wynoszącą 20,5 miesiąca. Autorzy konkludują, że status MRD ma istotne znaczenie rokownicze $\mathrm{u}$ chorych na AML. Pacjenci $z \operatorname{MRD}(+)$ po indukcji nie odnoszą korzyści $z$ dalszej chemioterapii konwencjonalnej, a poprawę ich odległych wyników leczenia można uzyskać, stosując allo-HSCT [22].

Pierwsze wieloośrodkowe, prospektywne badanie dotyczące znaczenia MRD w dużej grupie chorych na AML przeprowadziła grupa HOVON/ /SAKK AML (HOVON/SAKK AML 42A). Spośród 517 zakwalifikowanych do badania chorych u 389 stwierdzono przynamniej jeden LAIP umożliwiający dalszą analizę. W rekrutacji pacjentów brało udział łącznie 31 ośrodków, a ocena MRD odbywała się w czterech specjalistycznych laboratoriach. Należy dodać, że lekarz prowadzący nie miał dostępu do wyników MRD pacjentów, podobnie jak laboratorium nie miało dostępu do danych klinicznych. W badaniu tym poddano walidacji punkt odcięcia dla wartości dodatniej MRD $(0,1 \%)$, określony wcześniej na podstawie badań retrospektywnych [23]. Oceny MRD dokonywano po indukcji ( 1 lub 2 cykle) oraz po konsolidacji. Dodatkowo po drugim kursie indukującym dokonano subanalizy w obrębie trzech grup ryzyka genetyczno-molekularnego (korzystnego, pośredniego i niekorzystnego), określonych w momencie rozpoznania. W badaniu tym potwierdzono znaczenie wartości dodatniej MRD jako niezależnego niekorzystnego czynnika ryzyka nawrotu choroby i zgonu u chorych na AML we wszystkich ocenianych punktach czasowych, tj. po pierwszym cyklu indukującym $(\mathrm{p}=0,005)$, po drugim cyklu indukującym $(\mathrm{p}<0,001)$ oraz po konsolidacji $(\mathrm{p}<0,001)$. Jednak, jak podkreślają sami autorzy, wczesna ocena MRD (po indukcji) może mieć kluczowe znaczenie w praktyce klinicznej, umożliwiając wybór optymalnego leczenia poremisyjnego. Istotny $z$ praktycznego punktu widzenia jest również fakt, że wartość prognostyczną MRD potwierdzono we wszystkich 
grupach genetyczno-molekularnych. Autorzy wnioskują, że poza czynnikami ryzyka określonymi $\mathrm{w}$ chwili rozpoznania badanie poziomu choroby resztkowej $\mathrm{w}$ trakcie terapii powinno stać się istotnym elementem oceny ryzyka nawrotu u chorych na AML [24].

Podobnie jak u dorosłych, również u dzieci z AML potwierdzono istotny wplyw choroby resztkowej na rokowanie. $\mathrm{W}$ jednym $z$ badań Loken i wsp. [25] określali poziom MRD u dzieci, które uzyskały morfologiczną CR, po każdym z dwóch kursów indukujących oraz na zakończenie leczenia. Oceny MRD dokonywano metodą MFC według zasady different from normal i przedstawiano jako odsetek w stosunku do wszystkich nieerytroidalnych komórek jądrzastych szpiku (CD45+). Wykazano, że na każdym etapie leczenia pacjenci $z$ $\mathrm{MRD}(+)$ charakteryzują się gorszym rokowaniem niż chorzy z MRD(-). Ryzyko nawrotu choroby (RR, relapse rate) $\mathrm{w}$ ciagu 3 lat $\mathrm{u}$ chorych $\mathrm{z} \mathrm{MRD}(+)$ po pierwszej indukcji wynosiło $60 \% \mathrm{w}$ porównaniu z $29 \%$ u pacjentów $z$ MRD(-) (p $<0,001)$. $Z$ kolei 3-letni RFS wyniós1, odpowiednio, 30\% i $65 \%$ $(\mathrm{p}<0,001)$, a OS $-56 \%$ i $80 \%(\mathrm{p}=0,002)$. Po drugiej indukcji RR wynosiło 67\% i 30\% (p<0,001), a RFS $-29 \%$ i $65 \%(\mathrm{p}<0,001)$, natomiast w ocenie na zakończenie leczenia RR miało wartości 83\% i36\% ( $<<0,001)$, a RFS - 17\% i 62\% ( $<<0,001)$, odpowiednio, u chorych z MRD(+) oraz z MRD(-). Badacze przeprowadzili również ciekawą analizę znaczenia rokowniczego negatywizacji MRD w trakcie leczenia. Dowiedziono, że u pacjentów $z \mathrm{MRD}(-)$ po zakończeniu terapii, u których nigdy wcześniej nie stwierdzano choroby resztkowej, ryzyko wznowy $\mathrm{w}$ ciągu 3 lat wyniosło $26 \%$, a RFS $-75 \%$. $Z$ kolei chorzy z MRD $(+)$ na dowolnym etapie leczenia, mimo negatywizacji MRD po jego zakończeniu, pozostawali pacjentami obciążonymi wysokim ryzykiem (3-letnie $\mathrm{RR}=65 \%, \mathrm{RFS}=26 \%$ ). $\mathrm{W}$ analizie wielowariantowej potwierdzono znaczenie MRD jako niezależnego czynnika rokowniczego. Interesującą obserwacją $z$ tego badania jest również fakt, że pacjenci bez CR w ocenie morfologicznej (> 5\% blastów w szpiku), ale cytometrycznie bez choroby resztkowej, osiagali długoletnie przeżycia, co wskazuje na większą czułość MFC w różnicowaniu blastów białaczkowych i prawidłowych komórek regenerującego szpiku [25].

Jedna $z$ ostatnich prac hiszpańskej grupy badawczej PETHEMA dostarczyła kolejnych argumentów przemawiających za przydatnością oceny MRD w określaniu ryzyka nawrotu u chorych na AML. W badaniu obejmującym 306 chorych $z$ de novo rozpoznaną AML, którzy osiągnęli morfologiczną CR po leczeniu indukującym, wyodrębniono trzy grupy ryzyka w zależności od poziomu MRD grupę wysokiego ryzyka, $z$ MRD równym $0,1 \%$ lub wyższym, grupę pośredniego ryzyka, $z$ MRD równym $0,01 \%$ lub wyższym, ale niższym od $0,1 \%$, grupę niskiego ryzyka z MRD niższym niż $0,01 \%$. Pięcioletni RFS w poszczególnych grupach wyniósł odpowiednio $38 \%, 50 \%$ i $71 \%(\mathrm{p}=0,002)$ [26]. Tym samym zwalidowano ustalone na podstawie wcześniejszych badań progi odcięcia dla wartości MRD [21]. Prognostyczne znaczenie wartości MRD potwierdzono również $\mathrm{w}$ grupach niekorzystnego $(\mathrm{p}=0,02)$ i pośredniego $(\mathrm{p}=0,03)$ ryzyka cytogenetyczno-molekularnego oraz tendencję $\mathrm{w}$ tym kierunku $(\mathrm{p}=0,3) \mathrm{w}$ grupie ryzyka korzystnego. Badacze analizowali również znaczenie rokownicze MRD w odniesieniu do rodzaju zastosowanej terapii konsolidującej. Wśród pacjentów poddanych przeszczepieniu autologicznych krwiotwórczych komórek macierzystych (auto-HSCT, autologous hematopoietic stem cell transplantation) status MRD po indukcji pozwalał na wyodrębnienie trzech grup ryzyka $z$ 5-letnim RFS wynoszącym $40 \%, 57 \%$ i $83 \%(p=0,02)$, odpowiednio, dla grup ryzyka wysokiego, pośredniego i niskiego. W grupie osób poddanych allo-HSCT również wyodrębniono trzy grupy ryzyka (5-letni RFS 53\%, 62\%, 75\%), jednak nie uzyskano istotności statystycznej. $Z$ kolei w grupie chorych poddanych chemioterapii konsolidującej tylko pacjenci $z$ grupy niskiego ryzyka ( $\mathrm{tj}$. $z \mathrm{MRD}<0,01 \%$ ) osiągali zadowalające przeżycia (5-letni RFS 67\%), a pozostali chorzy $-z$ grup ryzyka pośredniego i wysokiego - charakteryzowali się bardzo złym rokowaniem (5-letni RFS, odpowiednio, $11 \%$ i $28 \%$; $p=0,07$ ).

$Z$ jednej strony powyższe wyniki wskazują, że bez względu na rodzaj zastosowanej terapii konsolidującej rokowanie pacjentów było tym gorsze, im wyższy był poziom MRD po leczeniu indukującym. $Z$ drugiej strony $\mathrm{w}$ grupach ryzyka pośredniego i wysokiego (tj. $z$ MRD $\geq 0,01 \%$ i $<0,1 \%$ oraz MRD $\geq 0,1 \%$ ) zadowalające efekty osiagali tylko pacjenci poddani allo-HSCT (5-letni RFS, odpowiednio, 63\% i 55\%). Autorzy badania zaproponowali również nowy system prognostyczny, lączący MRD i zmiany cytogenetyczno-molekularne. Przyznając 0, 1 lub 2 punkty za każdą kategorię ryzyka, odpowiednio: niskiego/korzystnego, pośredniego i wysokiego/ /niekorzystnego, wyodrębniono pięć grup ryzyka (0-4 pkt.) różniących się rokowaniem (5-letni RFS, odpowiednio, $100 \%, 70 \%, 54 \%, 35 \%, 19 \%$; $\mathrm{p}<0,001)[26]$. 


\section{Znaczenie prognostyczne oceny MRD przed allo-HSCT}

Ocena znaczenia prognostycznego MRD $\mathrm{w}$ aspekcie przeszczepienia krwiotwórczych komórek macierzystych (HSCT, hematopoietic stem cell transplantation) również była przedmiotem badań. W jednym $z$ nich, obejmującym 99 pacjentów poddanych tej procedurze w pierwszej CR (CR1), Walter i wsp. [27] wykazali, że obecność MRD przed allo-HSCT $z$ kondycjonowaniem mieloablacyjnym jest niekorzystnym czynnikiem ryzyka wznowy i zgonu. Pacjenci z MRD(+) przed allo-HSCT (tj. $z$ dowolnym odsetkiem rezydualnych komórek białaczkowych), w porównaniu $z$ chorymi z MRD(-) (bez wykrywalnej choroby resztkowej), charakteryzowali się istotnie niższym przewidywanym 2-letnim OS $(30,2 \% v$. 76,6\%; p < 0,001) oraz wyższym ryzykiem wznowy w ciągu 2 lat $(64,9 \%$ v. 17,6\%; $\mathrm{p}<0,001)$. W analizie wielowariantowej obecność MRD okazała się niezależnym czynnikiem ryzyka wznowy i zgonu [27]. W innym badaniu tych samych autorów podobną zależność udało się potwierdzić w grupie chorych na AML poddanych allo-HSCT w drugiej CR (CR2). Co więcej, badacze wykazali, że każdy poziom MRD, nawet równy $0,1 \%$ lub niższy, wiązał się $z$ niekorzystnym rokowaniem. $Z$ kolei wzrost odsetka MRD wśród pacjentów $z \mathrm{MRD}(+)$ nie wiązał się w sposób istotny statystycznie $z$ dalszym wzrostem ryzyka wznowy, choć autorzy zastrzegają, że ze względu na stosunkowo małą liczebność grupy $\mathrm{MRD}(+)$ takiej zależności nie można zupełnie wykluczyć [28].

W kolejnym badaniu Walter i wsp. [29] oceniali, czy obecność MRD będzie miała podobny negatywny wpływ na rokowanie u pacjentów z AML w CR1 poddanych allo-HSCT $z$ kondycjonowaniem o zredukowanej intensywności (RIC, reduced-intensity conditioning). Badacze podzielili 241 chorych na dwie grupy w zależności od typu kondycjonowania - mieloablacyjnego (MA, myeloablative), obejmującą 155 pacjentów oraz RIC obejmującą 86 pacjentów. Szacunkowe ryzyko wznowy w ciągu 3 lat dla chorych $z \operatorname{MRD}(-)$, w porównaniu $z$ tymi $z \mathrm{MRD}(+)$ w grupie RIC, wynosiły, odpowiednio, $28 \%$ i $57 \%$ ( $\mathrm{p}=0,005)$, a w grupie MA, odpowiednio, $22 \%$ i $63 \%$ (p < 0,001). $Z$ kolei przewidywane 3-letnie OS nie różniło się istotnie w grupie RIC w zależności od statusu MRD (48\% w grupie $z \operatorname{MRD}(-)$ i $41 \%$ w grupie $z \operatorname{MRD}(+) ; p=$ $=0,457$ ), inaczej niż $\mathrm{w}$ grupie MA (odpowiednio $76 \%$ i $25 \%$; $p<0,001)$. Brak różnicy pod względem
OS w grupie RIC autorzy tłumaczą wysokim odsetkiem śmiertelności niezwiązanej ze wznową (NRM, non-relapse mortality) (30\%) wśród pacjentów $z \mathrm{MRD}(-)$ w porównaniu $z$ pacjentami $z \mathrm{MRD}(+)$ $(10 \%)$. W grupie MA odsetki te były odwrotne (odpowiednio 7\% i 23\%). W powyższym badaniu wykazano podobny negatywny wpływ obecności choroby resztkowej przed allo-HSCT na ryzyko wznowy bez względu na typ kondycjonowania [29].

Znaczenie prognostyczne obecności choroby resztkowej przed allo-HSCT było także przedmiotem analizy Anthias i wsp. [30] przeprowadzonej wśród 88 pacjentów z AML w pierwszej lub kolejnych remisjach. Za wartość dodatnią MRD uznano jakikolwiek poziom choroby resztkowej i pacjentów podzielono na trzy grupy: $\mathrm{MRD}(-), \mathrm{z}$ niskim poziomem MRD ( $<1 \%$ ) oraz $\mathrm{Z}$ wysokim poziomem $\operatorname{MRD}(\geq 1 \% \mathrm{i}<5 \%)$. Inaczej niż w badaniu Waltera i wsp., przewidywany 2-letni OS różnił się istotnie w poszczególnych grupach pacjentów, osiągając wartości $66,8 \%, 51 \%$ i $30 \%$, odpowiednio, u chorych z MRD(-), z niskim oraz $z$ wysokim poziomem MRD $(\mathrm{p}=0,012)$. Podobną zależność wykazano również $\mathrm{w}$ podgrupie $z$ kondycjonowaniem RIC (odpowiednio 65\%, 50,5\% i 25\%; $\mathrm{p}=0,015$ ). $Z$ kolei ryzyko wznowy w ciagu 2 lat $(70 \%)$ było 2 -krotnie wyższe $\mathrm{w}$ grupie $z$ wysokim poziomem MRD W porównaniu $z$ grupą $z$ niskim poziomem MRD (37\%) i ponad 9-krotnie wyższe niż u pacjentów $\mathrm{MRD}(-)$ przed transplantacją $(7,6 \%)(\mathrm{p}<0,001)$. Autorzy podsumowali, że choć znaczenie statusu MRD przed allo-HSCT jako niezależnego czynnika ryzyka wymaga potwierdzenia $\mathrm{w}$ prospektywnych badaniach, to parametr ten może być bardzo pomocny w modyfikowaniu leczenia $u$ chorych na AML poddawanych tej procedurze, na przykład poprzez modyfikację protokołu kondycjonowania, wzmacnianie efektu przeszczep przeciwko białaczce (GvL, graft versus leukemia) dzięki wcześniejszemu wycofaniu się z leczenia immunosupresyjnego lub stosowanie infuzji limfocytów dawcy (DLI, donor lymphocyte infusion) [30].

Kolejną kwestią jest źródło krwiotwórczych komórek macierzystych. Według obserwacji niektórych autorów obecność choroby resztkowej przed allo-HSCT zwiększa ryzyko wznowy w przypadku przeszczepienia od dawcy rodzinnego lub zgodnego dawcy niespokrewnionego, ale nie wpływa negatywnie na rokowanie, gdy źródłem komórek krwiotwórczych jest krew pępowinowa. Najprawdopodobniej wynika to ze zwiększonego efektu GvL [31]. 


\section{Rola MRD u chorych na AML powyżej 60. roku życia}

Większość chorych na AML to osoby starsze, powyżej 60. roku życia, u których rokowanie jest gorsze niż u chorych młodszych. Dzięki zastosowaniu intensywnej chemioterapii 45-65\% starszych chorych uzyskuje CR, jednak aż u około $80 \%$ pacjentów dochodzi do wznowy choroby. W efekcie długoletnie przeżycia osiąga mniej niż $10 \%$ chorych [7,32]. Istotny wpływ na tak złe rokowanie u starszych pacjentów ma $z$ jednej strony bardziej agresywny charakter choroby (częściej obecne zmiany genetyczne o niekorzystnym rokowaniu i wtórny charakter białaczki), $z$ drugiej strony zaś częstsze choroby wspólistniejące i upośledzona wydolność narządowa. Badania służące ocenie znaczenia MRD w tej grupie chorych są mniej liczne. W jednym $z$ nich Freeman i wsp. [32] poddali prospektywnej analizie 427 pacjentów, którzy osiągnęli CR po jednym lub dwóch kursach indukujących, spośród chorych zakwalifikowanych do badania National Cancer Research Institute (NCRI-AML16). Obecność choroby resztkowej badano po każdym cyklu chemioterapii indukującej, a status $\mathrm{MRD}(+)$ oznaczał wykrycie jakiejkolwiek ilości komórek z LAIP (przy progu czułości $0,1 \%$ ). W badaniu tym wykazano, że grupa pacjentów $z \mathrm{MRD}(-)$ w stosunku do tych $z \mathrm{MRD}(+)$ charakteryzuje się wyższym odsetkiem 3-letniego OS (u chorych w CR po 1 . cyklu: $42 \%$ v. $26 \%$; $<<0,001$, u chorych w CR po 2. cyklu: $38 \%$ v. $18 \%$; p < 0,001), mniejszym odsetkiem nawrotów choroby, choć i tak nadal dość wysokim (u chorych w CR po 1 . cyklu: $71 \%$ v. $83 \%$; $\mathrm{p}<0,001$, u chorych $\mathrm{w}$ CR po 2 . cyklu: $79 \%$ v. $91 \% ; \mathrm{p}<0,001)$ oraz krótszym czasem do nawrotu (mediana $8,5 v \cdot 17,1$ miesiąca). W analizie wielowariantowej obecność choroby resztkowej po pierwszym cyklu indukującym była niezależnym niekorzystnym czynnikiem ryzyka wznowy [32].

Ciekawą analizą znaczenia prognostycznego MRD w zależności od wieku pacjentów była również praca Buccisano i wsp. [7]. Badacze podzielili chorych na cztery grupy, biorąc pod uwagę wiek ( $<60$ lat oraz $>60$ lat) oraz status MRD po konsolidacji - MRD(-) oraz MRD(+). Oceny choroby resztkowej dokonywano po każdym cyklu chemioterapii, a za wartość dodatnią uznano obecność 0,035\% lub więcej komórek z LAIP. Okazało się, że zarówno w grupie młodszych, jak i starszych chorych negatywizacja MRD wiązała się z lepszym rokowaniem. Pięcioletni czas wolny od choroby (DFS, disease-free survival) $\mathrm{w}$ grupie mlodszych chorych dotyczył $56 \%$ i $31 \%$, odpowiednio, pacjentów z MRD(-) i MRD(+), a w grupie starszych chorych $-57 \%$ i $13 \%(\mathrm{p}=0,0003)$, natomiast odsetki 5-letniego OS w młodszej grupie wiekowej wynosily, odpowiednio, $57 \%$ i $31 \%$, a w starszej $71 \%$ i $16 \%$ ( $\mathrm{p}=0,001) . Z$ kolei skumulowana częstość nawrotów (CIR, cumulative incidence of relapse) $\mathrm{w}$ ciagu 5 lat w grupie młodszych chorych osiągnęla wartości $24 \%$ i $59 \%$, a w starszej grupie - $42 \%$ i $83 \%$ ( $\mathrm{p}<0,0001$ ), odpowiednio, u pacjentów $z \mathrm{MRD}(-)$ i z $\mathrm{MRD}(+)$. Analiza wielowariantowa potwierdziła znaczenie MRD jako niezależnego czynnika ryzyka nawrotu choroby i zgonu. Autorzy podkreślili jednak, że mimo eradykacji MRD wśród starszych chorych nawroty choroby występowały dwa razy częściej niż w młodszej grupie wiekowej (42\% v. $24 \%$ ) i podsumowali, że status MRD może mieć odmienne implikacje kliniczne zależnie od wieku chorego. $\mathrm{O}$ ile u młodszych pacjentów w niektórych sytuacjach klinicznych (np. korzystne lub pośrednie ryzyko cytogenetyczne) brak MRD świadczy o dobrym rokowaniu, które przewyższa ryzyko związane $z$ allo-HSCT wykonywaną w CR1, o tyle wśród starszych chorych eliminacja MRD może usprawiedliwiać bardziej intensywne, stosownie do wieku, postępowanie (np. RIC allo-HSCT), $z$ szansą na poprawę odległych wyników leczenia. $Z$ kolei utrzymywanie się MRD po chemioterapii u młodych chorych silnie przemawia za zastosowaniem allo-HSCT, natomiast starsi pacjenci $z \mathrm{MRD}(+)$ stanowią grupę o bardzo niekorzystnym rokowaniu, dla której alternatywą może być udział w badaniach klinicznych [7].

\section{Minimalna choroba resztkowa a decyzje terapeutyczne}

Biorąc pod uwagę wyniki wcześniejszych badań potwierdzające przydatność MRD do ocen ryzyka wznowy u chorych na AML, Rubnitz i wsp. [33] wykonali kolejny krok, wykorzystując ten parametr do wyboru leczenia poremisyjnego u dzieci z AML (wieloośrodkowe badanie AML02, liczba chorych $=232$ ). Za punkt odcięcia dla pozytywnego wyniku MRD przyjęto wartość $0,1 \%$. Pacjenci $z$ wysokim poziomem MRD równym $1 \%$ lub wyższym po pierwszej indukcji (ocena 22 . dnia) byli kwalifikowani do niezwłocznego rozpoczęcia drugiego kursu indukującego, natomiast chorzy z MRD poniżej 1\% kontynuowali leczenie po pojawieniu się cech regeneracji hematopoezy. Ponadto pacjenci z MRD równym $1 \%$ lub wyższym $\mathrm{w}$ trakcie drugiej indukcji otrzymywali dodatkowo gemtuzumab ozogamycyny (GO). Co więcej, pacjentów z MRD utrzymującą się po 3 kursach 
chemioterapii uznawano za chorych wysokiego ryzyka i kierowano na allo-HSCT. Spośród 29 chorych, którzy z powodu wysokiego poziomu MRD po pierwszej indukcji w drugiej indukcji otrzymali dodatkowo GO, u 27 uzyskano redukcje poziomu MRD i u prawie połowy $z$ nich stwierdzono eradykację choroby resztkowej. $Z$ kolei w grupie pacjentów obciążonych wysokim ryzykiem, $z$ poziomem MRD powyżej $1 \%$ po pierwszej indukcji, których poddano allo-HSCT, zaobserwowano trend w kierunku wydłużenia OS w stosunku do chorych $\mathrm{z}$ tej grupy niepoddanych procedurze allo-HSCT $(43,5 \%$ v. 23,1\%, p = 0,14). Warto wspomnieć, że badacze wykorzystali również MRD do wstępnej oceny skuteczności eskalacji dawki arabinozydu cytozyny (Ara-C) w schemacie indukującym ADE (Ara-C, daunorubicyna, etopozyd). Pacjenci zostali poddani randomizacji do grup leczonych dużymi (łącznie $18 \mathrm{~g} / \mathrm{m}^{2}$ ) lub małymi (łącznie $2 \mathrm{~g} / \mathrm{m}^{2}$ ) dawkami Ara-C. Okazało się, że po pierwszej indukcji odsetek pacjentów $z$ MRD $(+)$ był mniejszy w grupie leczonej dużymi dawkami Ara-C, jednak nie była to różnica istotna statystycznie $(34 \% v .42 \%$; $\mathrm{p}=0,17)$. Podobnie nie stwierdzono istotnych statystycznie różnic między tymi grupami w zakresie przeżycia wolnego od zdarzeń (EFS, event-free survival) $(60,2 \%$ v. $65,7 \%$; $\mathrm{p}=0,41)$, OS $(68,8 \%$ v. $73,4 \% ; \mathrm{p}=0,41), \mathrm{RR}$ $(17,5 \%$ v. $21,5 \% ; \mathrm{p}=0,5)$ ani zgonów niezwiązanych ze wznową $(11,9 \%$ v. $5,5 \%$; $\mathrm{p}=0,13)$ [33].

Optymalne dawkowanie Ara-C w indukcji remisji, tym razem $u$ dorosłych chorych na AML, było przedmiotem retrospektywnej analizy Maurillo i wsp. [34]. Badacze oceniali skuteczność dużych (HD-Ara-C [high-dose Ara-C], $3 \mathrm{~g} / \mathrm{m}^{2}$ co $12 \mathrm{~h}$ przez $4 \mathrm{dni}$ ) i standardowych dawek Ara-C (SD-Ara-C [standard-dose Ara-C], $100 \mathrm{mg} /$ $/ \mathrm{m}^{2} \mathrm{w}$ ciągłej infuzji przez $10 \mathrm{dni}$ ) w schematach zawierających poza tym daunorubicynę i etopozyd. W powyższym badaniu za wartość dodatnią MRD uznano wyższą lub równą 0,035\% komórek z LAIP. Zarówno po indukcji, jak i po konsolidacji negatywizacja MRD była istotnie częstsza $\mathrm{w}$ grupie lecznonej SD-Ara-C niż w grupie leczonej HD-Ara-C (odpowiednio 37\% i 15\%; p = 0,007 po indukcji i $44 \%$ i $18 \%$; p $=0,002$ po konsolidacji). Nie stwierdzono również, podobnie jak w badaniu Rubnitza i wsp., by eskalacja dawki Ara-C $\mathrm{w}$ istotny sposób wpłynęła na poprawę przeżycia pacjentów. $Z$ kolei analiza wpływu statusu MRD na rokowanie $\mathrm{u}$ chorych na AML dowiodła istotnie większego prawdopodobieństwa 10-letnich RFS i OS w grupie $z \mathrm{MRD}(-)$ w porównaniu $z$ grupą $z$ MRD(+), ale tylko w ocenie po konsolidacji (RFS
$55,5 \%$ v. $27,9 \% ; \mathrm{p}=0,002$; OS $55,4 \%$ v. $32,7 \%$; $\mathrm{p}=0,02)$. W badaniu tym dokonano również analizy w czterech podgrupach wyodrębnionych na podstawie zastosowanej dawki Ara-C oraz statusu MRD: SD-Ara-C MRD(-), HD-Ara-C MRD(-), SD-Ara-C $\mathrm{MRD}(+)$, HD-Ara-C MRD(+). Ponownie okazało się, że tylko w ocenie po konsolidacji odnotowano istotne statystycznie różnice w zakresie RFS, OS i CIR, wskazujące na grupę SD-Ara-C MRD(-) jako najlepiej rokującą (prawdopodobieństwo 10-letniego RFS $61,3 \%$; $=0,001$; OS $61,2 \%$; $p=0,01$; CIR 23,7\%; p < 0,0001). Autorzy podsumowali, że poza wartością rokowniczą ocena MRD może być użytecznym surogatem punktów końcowych w badaniach klinicznych, w których ustala się optymalne dawki leków cytostatycznych i ocenia ich skuteczność [34].

\section{Podsumowanie}

Niekorzystne rokowanie u chorych na AML oraz heterogenność tej choroby zmusza do poszukiwania zarówno nowych terapii, jak i czynników prognostycznych umożliwiających zastosowanie najbardziej optymalnego leczenia w danej sytuacji klinicznej. W tym zakresie ocena MRD za pomocą MFC wydaje się obiecującym narzędziem. Rozbieżności między morfologiczną i cytometryczną oceną odsetka blastów oraz stosunkowo dobre rokowanie u pacjentów bez MRD mimo braku morfologicznej CR uzasadniają ocenę tego parametru u wszystkich chorych, a nie tylko tych, którzy osiągnęli morfologiczną CR [20].

Wysoka wartość predykcyjna dodatniego wyniku MRD przemawia za włączeniem tego parametru do całościowej oceny ryzyka i planowania leczenia poremisyjnego. Wyniki badań wskazują, że efekty intensyfikacji leczenia za pomocą allo-HSCT u pacjentów $z \mathrm{MRD}(+)$ są lepsze w porównaniu $z$ chemioterapią konwencjonalną [22, 26,33]. Wydaje się jednak, że na obecnym etapie wiedzy wartość predykcyjna ujemnego wyniku MRD nie jest zadowalająca. $U$ około $1 / 3$ chorych $z$ takim wynikiem MRD po leczeniu indukującym i konsolidującym obserwuje się wznowę choroby [14]. Zatem ujemny wynik MRD nie może upoważniać do podejmowania decyzji terapeutycznych o deeskalacji intensywności leczenia.

Aby decyzje terapeutyczne w codziennej praktyce klinicznej mogły być podejmowanie na podstawie statusu MRD, konieczne są standaryzacja metody oraz ujednolicenie definicji wartości dodatniej MRD rozumianej albo jako każda liczba rezydualnych komórek białaczkowych, albo jako wartość powyżej 
określonego punktu odcięcia, być może różnego w zależności od punktu czasowego oceny.

Przedstawione wyżej wnioski będą wymagały potwierdzenia w wieloośrodkowych prospektywnych badaniach uwzględniających w swoich protokołach ocenę choroby resztkowej, w tym LSC, wystandaryzowaną metodą $\mathrm{MFC} \mathrm{z}$ intensyfikacją leczenia u pacjentów $z$ chorobą resztkową (MRD/ /LSC) po leczeniu indukującym i konsolidującym.

\section{Piśmiennictwo}

1. Holowiecki J., Grosicki S., Giebel S. i wsp. Cladribine, but not fludarabine, added to daunorubicin and cytarabine during induction prolongs survival of patients with acute myeloid leukemia: a multicenter, randomized phase III study. J. Clin. Oncol. 2012; 30: 2441-2448.

2. Surveillance, Epidemiology and end Results. Dostępne na: seer. cancer.gov/statfacts/html/amyl.html. Data dostępu: 13.09.2016 r.

3. Al-Mawali A., Gillis D., Lewis I. The role of multiparameter flow cytometry for detection of minimal residual disease in acute myeloid leukemia. Am. J. Clin. Pathol. 2009; 131: 16-26.

4. Inaba H., Coustan-Smith E., Cao X. i wsp. Comparative analysis of different approaches to measure treatment response in acute myeloid leukemia. J. Clin. Oncol. 2012; 30: 3625-3632.

5. Grimwade D., Hills R.K., Moorman A.V. i wsp. Refinement of cytogenetic classification in acute myeloid leukemia: determination of prognostic significance of rare recurring chromosomal abnormalities among 5876 younger adult patients treated in the United Kingdom Medical Research Council trials. Blood 2010; 116: 354-365.

6. Grimwade D., Hills R.K. Independent prognostic factors for AML outcome. Hematology Am. Soc. Hematol. Educ. Program 2009: 385-395.

7. Buccisano F., Maurillo L., Piciocchi A. i wsp. Minimal residual disease negativity in elderly patients with acute myeloid leukemia may indicate different postremission strategies than in younger patients. Ann. Hematol. 2015; 94: 1319-1326.

8. Appelbaum F.R., Kopecky K.J., Tallman M.S. i wsp. The clinical spectrum of adult acute myeloid leukaemia associated with core binding factor translocations. Br. J. Haematol. 2006; 135: 165-173.

9. Holowiecki J., Krawczyk-Kulis M., Giebel S. i wsp. Status of minimal residual disease after induction predicts outcome in both standard and high-risk Ph-negative adult acute lymphoblastic leukaemia. The Polish Adult Leukemia Group ALL 4-2002 MRD Study. Br. J. Haematol. 2008; 142: 227-237.

10. Kayser S., Walter R.B., Stock W., Schlenk R.F. Minimal residual disease in acute myeloid leukemia-current status and future perspectives. Curr. Hematol. Malig. Rep. 2015; 10: 132-144.

11. Jaso J.M., Wang S.A., Jorgensen J.L., Lin P. Multi-color flow cytometric immunophenotyping for detection of minimal residual disease in AML: past, present and future. Bone Marrow Transplant. 2014; 49: 1129-1138.

12. San Miguel J.F., Martinez A., Macedo A. i wsp. Immunophenotyping investigation of minimal residual disease is a useful approach for predicting relapse in acute myeloid leukemia patients. Blood 1997; 90: 2465-2470.

13. Al-Mawali A., Gillis D., Hissaria P., Lewis I. Incidence, sensitivity, and specificity of leukemia-associated phenotypes in acute myeloid leukemia using specific five-color multiparameter flow cytometry. Am. J. Clin. Pathol. 2008; 129: 934-945.

14. Grimwade D., Freeman S.D. Defining minimal residual disease in acute myeloid leukemia: which platforms are ready for "prime time"? Blood 2014; 124: 3345-3355.

15. Voskova D., Schoch C., Schnittger S., Hiddemann W., Haferlach T., Kern W. Stability of leukemia-associated aberrant immunophenotypes in patients with acute myeloid leukemia between diagnosis and relapse: comparison with cytomorphologic, cytogenetic, and molecular genetic findings. Cytometry B Clin. Cytom. 2004; 62: 25-38.

16. Buccisano F., Maurillo L., Del Principe M.I. i wsp. Prognostic and therapeutic implications of minimal residual disease detection in acute myeloid leukemia. Blood 2012; 119: 332-341.

17. Baer M.R. High frequency of immunophenotype changes in acute myeloid leukemia at relapse: Implications for residual disease detection (Cancer and Leukemia Group B Study 8361). Blood 2001; 97: 3574-3580.

18. van Rhenen A., van Dongen, Guus A.M.S. i wsp. The novel AML stem cell associated antigen CLL-1 aids in discrimination between normal and leukemic stem cells. Blood 2007; 110: 2659-2666.

19. Terwijn M., Zeijlemaker W., Kelder A. i wsp. Leukemic stem cell frequency: a strong biomarker for clinical outcome in acute myeloid leukemia. PLoS Oone 2014; 9: e107587.

20. Paietta E. Should minimal residual disease guide therapy in AML? Best Pract. Res. Clin. Haematol. 2015; 28: 98-105.

21. San Miguel J.F. Early immunophenotypical evaluation of minimal residual disease in acute myeloid leukemia identifies different patient risk groups and may contribute to postinduction treatment stratification. Blood 2001; 98: 1746-1751.

22. Inoue D., Maruoka H., Takahashi T. Clinical analysis and optimization of post-remission therapy for acute myeloid leukemia patients with minimal residual disease as determined by flow cytometry. Mediterr. J. Hematol. Infect. Dis. 2010; 2: 2010020.

23. Feller N., van der Pol M.A., van Stijn A. i wsp. MRD parameters using immunophenotypic detection methods are highly reliable in predicting survival in acute myeloid leukaemia. Leukemia 2004; 18: 1380-1390.

24. Terwijn M., van Putten W.L.J., Kelder A. i wsp. High prognostic impact of flow cytometric minimal residual disease detection in acute myeloid leukemia: data from the HOVON/SAKK AML 42A study. J. Clin. Oncol. 2013; 31: 3889-3897.

25. Loken M.R., Alonzo T.A., Pardo L. i wsp. Residual disease detected by multidimensional flow cytometry signifies high relapse risk in patients with de novo acute myeloid leukemia: a report from Children's Oncology Group. Blood 2012; 120: 1581-1588.

26. Vidriales M., Pérez-López E., Pegenaute C. i wsp. Minimal residual disease evaluation by flow cytometry is a complementary tool to cytogenetics for treatment decisions in acute myeloid leukaemia. Leuk. Res. 2016; 40: 1-9.

27. Walter R.B., Gooley T.A., Wood B.L. i wsp. Impact of pretransplantation minimal residual disease, as detected by multiparametric flow cytometry, on outcome of myeloablative hematopoietic cell transplantation for acute myeloid leukemia. J. Clin. Oncol. 2011; 29: 1190-1197.

28. Walter R.B., Buckley S.A., Pagel J.M. i wsp. Significance of minimal residual disease before myeloablative allogeneic hematopoietic cell transplantation for AML in first and second complete remission. Blood 2013; 122: 1813-1821.

29. Walter R.B., Gyurkocza B., Storer B.E. i wsp. Comparison of minimal residual disease as outcome predictor for AML patients 
in first complete remission undergoing myeloablative or nonmyeloablative allogeneic hematopoietic cell transplantation. Leukemia 2014; 29: 137-144.

30. Anthias C., Dignan F.L., Morilla R. i wsp. Pre-transplant MRD predicts outcome following reduced-intensity and myeloablative allogeneic hemopoietic SCT in AML. Bone Marrow Transplant. 2014; 49: 679-683.

31. Appelbaum F.R. Hematopoietic cell transplantation for adults with acute myeloid leukemia with minimal residual disease. Best Pract. Res. Clin. Haematol. 2015; 28: 133-140.
32. Freeman S.D., Virgo P., Couzens S. i wsp. Prognostic relevance of treatment response measured by flow cytometric residual disease detection in older patients with acute myeloid leukemia. J. Clin. Oncol. 2013; 31: 4123-4131.

33. Rubnitz J.E., Inaba H., Dahl G. i wsp. Minimal residual disease-directed therapy for childhood acute myeloid leukaemia: results of the AML02 multicentre trial. Lancet Oncol. 2010; 11: 543-552.

34. Maurillo L., Buccisano F., Piciocchi A. i wsp. Minimal residual disease as biomarker for optimal biologic dosing of ARA-C in patients with acute myeloid leukemia. Am. J. Hematol. 2015; 90: 125-131. 